\section{Discoversys \\ Published by DiscoverSys \\ Association between physical activity, fiber and salt intake with hypertension in adolescents with obesity}

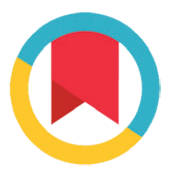

CrossMark

Ni Luh Putu Sudiasih, ${ }^{*}$ Dewa Nyoman Wirawan, ${ }^{2}$ I Gusti Lanang Sidiartha ${ }^{3}$

\title{
ABSTRACT
}

Background and purpose: There are indications that the prevalence of obesity among adolescents is increasing which is one of the main factors of hypertension. This study aims to determine the association between hypertension among obese adolescents with physical activity, fiber and salt intake.

Methods: This study used a cross-sectional design among obese adolescents aged 12-15 years. The study was conducted at six public/ private middle schools in the North Denpasar Sub-district, Denpasar City, Bali Province. The samples of 203 children were selected from the results of obesity screening conducted by North Denpasar III Public Health Center (PHC). Data collection was conducted over July-September 2018 with data included social demographics, body weight and height, blood pressure, consumption frequency of vegetables, fruits and high salt content foods, and physical activity carried out in the past week. Data analysis with logistic regression was conducted to determine the association between physical activity, fiber and salt intake with hypertension among obese adolescents.

Results: This study found that of 203 respondents, 14.8\% had hypertension. Multivariate analysis showed that hypertension in obese adolescents was associated with salt intake $\geq 1500 \mathrm{mg} /$ day with adjusted odd ratio (AOR) of 5.19 ( $95 \% \mathrm{Cl}: 2.20-12.22)$, inadequate physical activity (AOR=5.87; 95\%Cl: 1.19-29.00) and inadequate fiber intake (AOR=2.43;95\%Cl: 0.27-21.76).

Conclusion: Salt intake $\geq 1500 \mathrm{mg} /$ day and inadequate physical activity are associated with hypertension among obese adolescents. A reduction in the consumption of processed foods that are high in salt and increasing physical activity would improve adolescent health.
${ }^{1}$ Public Health Postgraduate Program, Faculty of Medicine, Udayana University,

${ }^{2}$ Department of Public Health and Preventive Medicine, Faculty of Medicine, Udayana University, ${ }^{3}$ Department of Pediatrics, Faculty of Medicine, Udayana University

*Correspondence to: Ni Luh Putu Sudiasih, Public Health Postgraduate Program, Faculty of Medicine, Udayana University, putu.sudiasih13@yahoo.com

Keywords: hypertension, salt intake, physical activity, adolescent obesity Cite This Article: Sudiasih, N.L.P., Wirawan, D.N., Sidiartha, I.G.L. 2019. Association between physical activity, fiber and salt intake with hypertension in adolescents with obesity. Public Health and Preventive Medicine Archive 7(1):54-59. D01:10.15562/phpma.v7i1.195

\section{INTRODUCTION}

The prevalence of obesity in adolescents aged $13-15$ years in Indonesia has increased from $2.5 \%$ in 2010 to $10.8 \%$ in $2013 .^{1,2}$ The prevalence of obesity among adolescents in Bali in 2013 was reported above the national prevalence of $13.9 \% .^{2}$ Obesity in adolescents can cause various health problems at a young age including heart disease, stroke, type 2 diabetes millitus, hypertension, osteoarthritis, dyslipidemia, asthma, sleep apnea, gallbladder disease and several types of cancer (endometrium, breast and large intestine). ${ }^{3}$

The prevalence of hypertension among obese children were reported between 21\%-53\%.4-6 Studies on risk factors for hypertension in overweight and obese adolescents show various results. Risk factors related to hypertension of obese adolescents include a history of parental hypertension, puberty, gender, genetic factors, insulin resistance and hypertriglyceridemia, blood glucose and cholesterol levels, high energy and low nutrition food consumption, fiber and salt consumption and low levels of physical activity. ${ }^{7-19}$
The pattern of food consumption in urban communities in Indonesia leads to reduced consumption of vegetables and fruits and tends to consume ready-to-eat foods (from high-carbohydrate, high-fiber and low-fat consumption patterns to low-carbohydrate and low-fiber, high-fat and high protein consumption patterns). ${ }^{2,20}$ Globally, $81 \%$ of adolescents aged between 11-17 years do not engage in moderate to high physical activity in alignment with recommendations for 60 minutes/ day. ${ }^{21}$ Young women are less active than young men, $85 \%$ compared to $78 \%$ do not meet WHO recommendations. ${ }^{21}$ Sedentary physical activities that increase the risk for hypertension among obese adolescents, includes watching TV, playing video games and a lack of physical activity (duration and intensity)..$^{10,14}$

This study aims to determine the association between physical activity, fiber and salt intake with hypertension among obese adolescents in order to inform the development of hypertension prevention programs among obese adolescents. 


\section{METHODS}

A cross-sectional study was conducted at public and private middle schools (junior high schools) in Denpasar City, Bali Province. The City of Denpasar consists of 4 sub-districts with a total of 74 public and private middle schools. This study was conducted in the North Denpasar Sub-district at all (six) public and private middle schools with around 4,317 students. The minimum sample size required was 125 children with $95 \%$ confidence level, $80 \%$ power, the proportion of hypertension among obese adolescents with high salt intake $=0.84$ and the proportion of hypertension among obese adolescents with low salt intake $=0.69 .{ }^{13}$ Data on obese school children were obtained from the North Denpasar III PHC which routinely screened nutritional status of adolescents. The samples of obese adolescents were selected from 252 adolescents in the 2017 PHC's screening list. A total of 49 children from those listed on the PHC screening list were excluded from the study because three children had a history of low birth weight, 9 children were absent from or had changed schools and 37 children had obstructive sleep apnea. All 203 eligible students were then included in our study. Data collection was conducted in July-September 2018 at the schools which included social demographic characteristics (age, gender and puberty status), weight, height, blood pressure, frequency of food consumption and physical activity. Measurements of weight were carried out in each school with a digital scale of GEA medical EF 981, heights were measured with OneMed brand HT701 model microtoise and blood pressure measurements carried out using calibrated OneMed brand tensimeter with 17-19 cm length and 7,5-9 $\mathrm{cm}$ width cuff size. Data on fiber and salt intake were collected using a semi quantitative food frequency questionnaire (SQFFQ) which included: frequency of consumption of vegetables, fruits and fatty foods that were high in salt over the past week. Data on physical activity in the past week was collected using a global physical activity questionnaire. Interviews were carried out after weight measurements were held in the classrooms of each school by researchers and trained enumerators.

Adolescent obesity is determined based on body mass index (BMI) calculated using the weight and height measurements that converted to Z-score based on the BMI World Health Organization curve according to age and sex, and determined as an obese child if Z-score $\geq 2 \mathrm{SD} .{ }^{22}$ Blood pressure in the study subjects was measured three times few minutes after weight measurement was conducted. Hypertension was determined with a comparison of systolic and diastolic percentiles according to CDC 2000 based on age, sex and height percentile. Based on the National High Blood Pressure Education Program (NHBPEP) Working Group on Children and Adolescents, hypertension is defined as the average systolic and/or diastolic blood pressure $\geq 120 / 80 \mathrm{mmHg}$ according to age, sex and height. ${ }^{23}$

Data about fiber and salt intake were analysed using the nutrient survey application to determine the adequacy of consumed nutrients. Nutrition adequacy was determined based on the 2013 Indonesian Ministry of Health Regulation No. 75 with the recommendations of $28 \mathrm{gr} /$ day and 30gr/day fiber minimum limits for female and male adolescents respectively and a minimum salt consumption limit of no more than $1500 \mathrm{mg} /$ day. ${ }^{24}$ Fiber intake was categorised based on the frequency of vegetable and fruits consumption over the past week and classified as "inadequate" if fiber consumption was $\leq 28 \mathrm{gr} /$ day. The classification of salt intake was determined by the frequency of consumption of foods with high salt content during the past week and classified as "high" if the salt consumption was $\geq 1500 \mathrm{mg} /$ day. Levels of physical activity were determined by that carried out by adolescents during the past week and classified as "inadequate" if $>40 \%$ of the time spent is for sitting or standing such as studying, watching TV, playing games and doing houseworks (washing dishes, ironing, cooking, sweeping and mopping the floor.

Bivariate analysis for numeric variables was conducted using t-test after the test for normality of the data distribution, and chi-square test was employed for categorical variables. Multivariate analysis was conducted with logistic regression using STATA 12.1 to obtain the AOR of each variable. This study has been approved by the Ethics Committee of the Faculty of Medicine, Udayana University/Sanglah General Hospital Denpasar on May 24, 2018.

\section{RESULTS}

Table 1 shows that the majority of respondents had reached puberty $(82.8 \%)$, were male $(58.1 \%)$, aged between 13 and 14 years (76.3\%) and $14.8 \%$ of adolescents experienced hypertension.

During the interview, apple was the main fiber source consumed by the students over the past week while fried eggs and anchovy were the main salt sources being reported. In Table 2, it is presented that there are significant differences on apple consumption, anchovy consumption and mean sedentary activity. The proportion of obese adolescents suffering from hypertension among those who consumed apples was found to be lower than those who did not consume apples, respectively $5.8 \%$ and $17.9 \%(p=0.03)$. The proportion of hypertension in obese adolescents who consumed 
Table 1 Characteristics of respondents

\begin{tabular}{lccc}
\hline Characteristics & $\begin{array}{c}\text { Hypertension } \\
\mathbf{n}(\%)\end{array}$ & $\begin{array}{c}\text { No hypertension } \\
\mathbf{n}(\%)\end{array}$ & Total \\
\hline Age (years) & $5(15.6)$ & $27(84.4)$ & $32(15.8)$ \\
12 & $11(13.6)$ & $70(86.4)$ & $81(39.9)$ \\
13 & $8(10.8)$ & $66(89.2)$ & $74(36.4)$ \\
14 & $6(37.5)$ & $10(62.5)$ & $16(7.9)$ \\
15 & & & $85(41.9)$ \\
Gender & $10(11.8)$ & $75(88.2)$ & $118(58.1)$ \\
Female & $20(16.9)$ & $98(83.1)$ & $35(17.2)$ \\
Male & & & $168(82.8)$ \\
Puberty status & $7(20.0)$ & $28(80.0)$ & $203(100.0)$ \\
Not in puberty & $29(13.7)$ & $145(86.3)$ & $173(85.2)$ \\
Puberty & $30(14.8)$ & & \\
Total & & & \\
\hline
\end{tabular}

Tabel 2 The association between food consumption and physical activity with hypertension in obese adolescents

\begin{tabular}{|c|c|c|c|}
\hline Variable & $\begin{array}{c}\text { Hypertension } \\
\mathrm{n}(\%)\end{array}$ & $\begin{array}{c}\text { No hypertension } \\
n(\%)\end{array}$ & $\mathbf{p}$ \\
\hline \multicolumn{4}{|c|}{ Apple consumption } \\
\hline Yes & $3(5.8)$ & $49(94.2)$ & \\
\hline No & $27(17.9)$ & $124(82.1)$ & 0.03 \\
\hline \multicolumn{4}{|c|}{ Fried egg consumption } \\
\hline Yes & $16(16.8)$ & $79(83.2)$ & \\
\hline No & $14(13.0)$ & $94(87.0)$ & 0.44 \\
\hline \multicolumn{4}{|c|}{ Anchovy consumption } \\
\hline Yes & $14(35.0)$ & $26(65.0)$ & \\
\hline No & $16(9.8)$ & $147(90.2)$ & $<0.01$ \\
\hline \multicolumn{4}{|c|}{ Physical activity } \\
\hline Inadequate & $2(5.7)$ & $33(94.3)$ & \\
\hline Adequate & $28(16.7)$ & $140(83.3)$ & 0.10 \\
\hline \multicolumn{4}{|c|}{ Fiber intake (gr) } \\
\hline Mean \pm SD & $10.1 \pm 5.7$ & $11.9 \pm 8.3$ & 0.27 \\
\hline \multicolumn{4}{|c|}{ Salt intake (mg) } \\
\hline Mean \pm SD & $1551.8 \pm 723.6$ & $1333.4 \pm 690.8$ & 0.11 \\
\hline \multicolumn{4}{|c|}{ Sedentary activity (minutes) } \\
\hline Mean \pm SD & $413 \pm 70$ & $390 \pm 54$ & 0.05 \\
\hline
\end{tabular}

Numeric variables were tested with t-test and categorical variables with chi-square test

anchovies was found to be higher than those who did not consume anchovies, $35 \%$ and $9.8 \%$ respectively $(\mathrm{p}<0.01)$. Test for normality of numerical data shows insignificant results and the mean difference was tested using t-test. The mean duration of sedentary activity was found to be higher in obese adolescents with hypertension than those without hypertension, 413 minutes/day and 390 minutes/ day respectively $(\mathrm{p}=0.05)$. There was no significant difference in the proportion of obese hypertensive adolescents by consumption of fried eggs $(\mathrm{p}=0.44)$, physical activity $(p=0.10)$, mean fiber intake $(p=0.27)$ and mean salt intake $(p=0.11)$.

In the multivariate analysis, sedentary activity was represented by physical activity which was categorized into "adequate" and "inadequate". Apple consumption was represented by fiber intake which categorized into "adequate" and 
Table 3 Adjusted OR of fiber and salt intake, physical activity, age, gender and puberty status with hypertension among obese adolescents

\begin{tabular}{|c|c|c|c|c|}
\hline \multirow[b]{2}{*}{ Variables } & \multirow[b]{2}{*}{ Adjusted OR } & \multicolumn{2}{|c|}{$95 \% \mathrm{Cl}$} & \multirow[b]{2}{*}{$\mathbf{p}$} \\
\hline & & Lower & Upper & \\
\hline \multicolumn{5}{|l|}{ Fiber intake } \\
\hline Adequate (>28 gr/day) & Ref & & & \\
\hline Inadequate ( $\leq 28 \mathrm{gr} /$ day $)$ & 2.43 & 0.27 & 21.76 & 0.43 \\
\hline \multicolumn{5}{|l|}{ Salt intake } \\
\hline Low (<1500 mg/day $)$ & Ref & & & \\
\hline $\operatorname{High}(\geq 1500$ mg/day $)$ & 5.19 & 2.20 & 12.22 & $<0.01$ \\
\hline \multicolumn{5}{|l|}{ Physical activity } \\
\hline Adequate ( $>60$ minutes/day) & Ref & & & \\
\hline Inadequate ( $\leq 60$ minutes/day) & 5.87 & 1.19 & 29.00 & 0.03 \\
\hline \multicolumn{5}{|l|}{ Age (years) } \\
\hline $12-13$ & Ref & & & \\
\hline $14-15$ & 1.41 & 0,54 & 3.67 & 0.48 \\
\hline \multicolumn{5}{|l|}{ Gender } \\
\hline Female & Ref & & & \\
\hline Male & 2.29 & 0.86 & 6.06 & 0.09 \\
\hline \multicolumn{5}{|l|}{ Puberty status } \\
\hline Not in puberty & Ref & & & \\
\hline Puberty & 0.58 & 0.16 & 2.03 & 0.40 \\
\hline
\end{tabular}

"inadequate". Fried egg and anchovy consumption were represented by salt intake which categorized into "low" and "high". All independent variables were included in the multivariate model. Table 3 shows that variables associated with hypertension in obese adolescents are salt intake $\geq 1500 \mathrm{mg} /$ day $(\mathrm{AOR}=5.19$; 95\%CI: 2.20-12.22) and lack of physical activity (AOR=5.87; 95\%CI: 1.19-29.00), while there is no association between hypertension and fiber intake (AOR=2.43; 95\%CI: 0.27-21.76).

\section{DISCUSSION}

In this study, the proportion of hypertension in obese adolescents aged 12-15 years was found to be $14.8 \%$. This finding is lower than in several previous cross-sectional studies, which reported that the prevalence of hypertension in obese adolescents was $21 \%-53 \%,{ }^{4-6}$ including a study on hypertension in adolescents in Denpasar City, which reported that the prevalence of hypertension was $30.6 \%{ }^{5}$ This difference is likely due to the different settings with our study and variations in the classification of hypertension in these studies. Some studies classified adolescents as having hypertension if their blood pressure is $\geq 95^{\text {th }}$ percentile in $\geq 3$ measurements. ${ }^{6}$ While in our study, we made three measurements, however the adolescents were classified to have hypertension if the blood pressure was $\geq 120 / 80 \mathrm{mmHg}$. Another possibility is due to differences in population characteristics where in our study more respondents came from public schools.

Our study shows that only two factors are significantly associated with hypertension in obese adolescents namely salt intake and inadequate physical activity, whereas fiber intake was not found to have a significant association. The findings of our study are similar with the results of a study in the City of Semarang which showed that salt intake was significantly associated with hypertension in obese adolescents. ${ }^{13}$ Based on the 2013 Indonesian Ministry of Health Regulation No. 75 regarding recommendations of nutritional adequacy, the minimum consumption limit of salt-containing foods is not more than $1500 \mathrm{mg} /$ day. ${ }^{24} \mathrm{In}$ our study, no significant differences were found in the mean of salt intake in hypertensive obese adolescents compared to those without hypertension, respectively $1551 \mathrm{mg} /$ day and $1333 \mathrm{mg} /$ day $(\mathrm{p}=0.11)$, however it was significantly associated with anchovies consumption. In our study, data on salt intake was collected using an SQFFQ and it was found that the main source of salt was also from anchovies. This leads to the significant association between salt intake and hypertension in the multivariate analysis. An American study showed that the amount of salt intake did not increase hypertension in children 
aged 8-18 years with AOR=1.98 (95\%CI: 0.95-4.11; $\mathrm{p}=0.06$ ), but significantly increased hypertension in obese children and adolescents with $\mathrm{AOR}=3.51$ (95\%CI: 1.34-9.20; $\mathrm{p}=0.01$ ). ${ }^{25}$ It was also reported that an increase in salt intake of $1,000 \mathrm{mg} /$ day increased the risk of hypertension by $74 \%$ in obese children and adolescents while only $6 \%$ in children and adolescents with normal body weight. ${ }^{25} \mathrm{~A}$ study in Iran found that some people are sensitive to salt, $50 \%$ in hypertensive people and $25 \%$ in normotensive people. ${ }^{26}$ Salt sensitivity and resistance are determined by various factors including: genetic, race, age, body mass, food quality and the presence of comorbidities related to other diseases including diabetes mellitus and renal dysfunction. ${ }^{26}$ Salt is naturally found in various foods and accounts for around $12 \%$ of total intake, while more than $75 \%$ of salt is added to food processing. ${ }^{26}$

In our study, lack of physical activity was found to increase the risk of hypertension in obese adolescents. Low levels of physical activity in our study included studying, watching TV, playing games and doing houseworks (ironing, cooking and washing dishes). Duration of sedentary physical activity outside school hours in obese adolescents with hypertension is 3-4 hours and 1-2 hours in obese adolescents without hypertension. Our study shows that obese adolescents who routinely carried out high physical activity with an average duration of 107 minutes/day (soccer, futsal, volleyball and gym) were only $11.8 \%$. WHO recommends that teens exercise for at least 60 minutes/day. ${ }^{27}$ The length of time for watching can reduce play and exercise time, thereby increasing the risk of hypertension in obese adolescents. ${ }^{28}$ Health benefits obtained from routine physical activity among adolescents include reduction in body fat, the risk of cardiovascular disease and symptoms of anxiety and depression, and also improved metabolism and bone health. ${ }^{21}$

Our study found that fiber intake was not significantly associated with hypertension in obese adolescents aged $12-15$ years with $\mathrm{AOR}=2.43$ (95\%CI: $0.27-21.76$ ). This is probably due to difficulties for the respondents when recalling food intake (information bias). Although hypertension in our study is quite low, it can be surmised that fiber consumption in Denpasar City is still below the nutritional adequacy rate recommended by the 2013 Indonesian Ministry of Health Regulation No. 75 , with a minimum limit of $28 \mathrm{gr} /$ day for adolescent fiber intake in women and $30 \mathrm{gr} /$ day in men. ${ }^{24}$ The results of our study are different from a study conducted in another country which shows that fiber intake is associated with hypertension in obese adolescents. ${ }^{5}$ Possible differences in these results could be due to differences in the number of samples, characteristics of subjects and methods of the data analysis. ${ }^{8}$

The limitation of our study is that not all obese adolescents were included in the PHC screening list. Another limitation is information bias due to recalling the intake and type of food consumed by children in one week before the interview. Our results may also be confounded by other variables such as fat intake which was not collected in our study. Finally, this study was carried out only in one sub-district in an urban area, so caution is needed in generalizing the results to a wider area.

\section{CONCLUSION}

Hypertension in obese adolescents has a significant association with salt intake and inadequate physical activity. Education about reducing salt consumption and increasing physical activity needs to be enhanced to reduce the incidence of hypertension among obese adolescents. Future studies are needed to understand this issue better.

\section{ACKNOWLEDGEMENT}

We would like to thank all of the respondents who have participated in this study, the School Principals and others who have facilitated the implementation of this study.

\section{REFERENCES}

1. Ministry of Health of Indonesia. The 2010 Indonesia Basic Health Research. Jakarta; 2010.

2. Ministry of Health of Indonesia. The 2013 Indonesia Basic Health Research. Jakarta; 2013.

3. World Health Organization. Obesity and overweight. Geneva; 2017.

4. Schwiebbe L, Talma H, Renders C. High prevalence of hypertension in obese children in the Caribbean. Paediatrics and International Child Health. 2012; 32(4): 204-7.

5. Purnami NMD. Prevalensi obesitas dan hubungan antara obesitas dengan kejadian hipertensi dan proteinuria pada anak usia 12-14 tahun di sekolah menengah pertama swasta di Kota Denpasar (Skripsi) [Obesity prevalence and the association of obesity with hypertension and proteinuria among 12-14 years old children in junior high schools in Denpasar City (Undergraduate thesis)]. Universitas Udayana; 2015.

6. Schwandt P, Scholze J, Bertsch T. Blood pressure percentiles in 22,051 Germany children and adolescents: the PEP Family Heart Study. American Journal of Hypertension. 2015; 28(5): 672-9.

7. Faienza M, Santoro N, Lauciello R, Calabrò R, Giordani L, DiSalvo G, et al. IGF2 gene variants and risk of hypertension in obese children and adolescents. Pediatric Research. 2010; 67(4): 340-4.

8. Puchau B, Ochoa M, Zulet M, Marti A. Dietary total antioxidant capacity and obesity in children and adolescents. International Journal of Food Sciences and Nutrition. 2010; 61(7): 713-21.

9. Benmohammed K, Nguyen MT, Khensal S, Valensi P, Lezzar A. Arterial hypertension in overweight and obese algerian adolescents: Role of abdominal adiposity. Diabetes \& Metabolism. 2011; 37: 291-7. 
10. Goldfield GS, Kenny GP, Hadjiyannakis S, Phillips P, Alberga AS, Saunders, et al. Video game playing is independently associated with blood pressure and lipids in overweight and obese adolescents. PLoS One. 2011; 6(11): $1-6$.

11. Siklar Z, Berberoglu M, Erdeve S, Hacihamdioglu B, Ocal G, Egin Y, et al. Contribution of clinical, metabolic, and genetic factors on hypertension in obese children and adolescents. Journal Pediatric Endocrine. 2011; 24(1-2): 21-4.

12. Souza-Costa D, Belo V, Silva P. eNOS haplotype associated with hypertension in obese children and adolescents. International Journal of Obesity. 2011; 35(3): 387-92.

13. Fattah L, Sulchan M. Asupan tinggi natrium dan berat badan lahir sebagai faktor risiko kejadian hipertensi obesitas pada remaja awal. Journal of Nutrition College. 2012; 1(1): 127-33.

14. Gopinath B, Baur LA, Hardy LL, Kifley A, Rose KA, Wong TY, et al. Relationship between a range of sedentary behaviours and blood pressure during early adolescence. Journal of Human Hypertension. 2012; 26(6): 350-6.

15. Lemes V, Neves A, Guazzelli I, Frazzatto E, Nicolau C, Corrêa-Giannella $\mathrm{M}$, et al. Angiotensin converting enzyme insertion/deletion polymorphism is associated with increased adiposity and blood pressure in obese children and adolescents. Gene. 2013; 532(2): 197-202.

16. Sulchan M. Consumption of energy-dense, nutrient-poor foods and hypertension in obese children. Paediatrica Indonesiana. 2014; 54(4): 236-44.

17. Hannon T, Gupta S, Li Z, Eckert G. The effect of body mass index on blood pressure varies by race among obese children. Journal Pediatric Endocrine Metabolic. 2015; 28(5-6): 533-8.

18. Permanasari $Y$, Aditiant. Konsumsi makanan tinggi kalori dan lemak tetapi rendah serat dan aktivitas fisik kaitannya dengan kegemukan pada anak usia 5 - 18 tahun di Indonesia [The association of consumption of high calories and fat but low fiber food and physical activities with obesity among 5-18 years children in Indonesia]. Penelitan Gizi dan Makanan. 2017; 40(2): 95-104.

19. Suryawan ZF. Analisis faktor yang berhubungan dengan hipertensi pada remaja [Analysis of factors associated with hypertension among teenagers]. Jurnal Keperawatan Muhammadiyah. 2019; 4(1): 136-149.
20. Santoso A. Serat pangan (dietary fiber) dan manfaatnya bagi kesehatan [Dietary fiber and the benefits for health]. Magistra. 2011; 23(75): 35-40.

21. World Health Organization. Global Health Observatory (GHO) data: Prevalence of insufficient physical activity. Geneva; 2018

22. World Health Organization. Obesity: preventing and managing the global epidemic. Geneva; 2000.

23. Falkner B, Daniels S, Flynn J, Gidding S. The fourth report on the diagnosis, evaluation, and treatment of high blood pressure in children and adolescents. Pediatrics. 2004; 114(2): 555-576.

24. Ministry of Health of Indonesia. Angka kecukupan gizi yang dianjurkan bagi rakyat Indonesia [Recommended dietary allowances for Indonesian population]. Jakarta; 2013.

25. Yang Q, Zhang Z, Kuklina E, Fang J, Ayala C, Hong Y, et al. Sodium intake and blood pressure among US children and adolescents. Pediatrics. 2012; 130(4): 611-9.

26. Samadian F, Dalili N, Jamalian A. Lifestyle modifications to prevent and control hypertension. Kidney Diseases. 2016; 10(5): 237-63.

27. World Health Organization. Global recommendations on physical activity for health. Geneva; 2018

28. Sulfa UF, Sulchan M, Fitranti DY. Makanan padat energi dan rendah mikronutrien sebagai faktor risiko kejadian obesitas pada remaja stunted usia 12-15 tahun di Kota Semarang (Skripsi) [High energy and low micronutrient foods as risk factors of obesity among stunted teenagers aged 12-15 years old in Semarang City (Undergraduate thesis)]. Universitas Diponegoro; 2017.

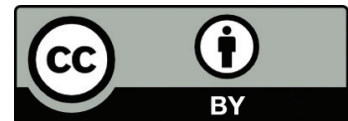

This work is licensed under a Creative Commons Attribution 